\section{ENGLISH LANGUAGE EDUCATION IN JAPAN: FROM WESTERNIZATION TO GLOBALIZATION}

\section{Tavicha Phadvibulya ${ }^{1}$}

\begin{abstract}
Japan is one of the most influential countries in the world's economy and politics. Although the country is perceived as being well-equipped technologically and having an industrious, highly literate, and energetic population, foreign language education, especially in English, has long been a critical issue. From the time of the Meiji Restoration (1868-1945), the Japanese have considered studying foreign languages to be tool to facilitate the Westernization of the country. It was also a key factor in Japan's recovery and rapid economic growth in the decades following the end of World War II (1945-1952). After the postwar period (1960s- present), however, foreign languages, previously seen as a one-way tool for absorbing Western civilization, became a tool for two-way communication where ideas are shared and exchanged. This has been due to the fact that, with the arrival of the $21^{\text {st }}$ century, Japanese society is facing many more challenges as a result of changing cultural norms, advances in science and, most importantly, the progress of globalization in the economy and in society. Accordingly, in 2002, the Japanese Ministry of Education, Culture, Sports, Science, and Technology (MEXT) inaugurated a policy for the improvement of communication skills in English,
\end{abstract}

\footnotetext{
${ }^{1} \mathrm{Ph} . \mathrm{D}$. candidate-English as an International Language Program, Chulalongkorn University
}

viewing it as essential for the Japanese to acquire communication skills in English as a common international language in order to function in the $21^{\text {st }}$ century. The series of reforms being introduced due to the changing needs of the country, including the efforts made, the outcomes gained and the quick expansion of foreign-language education, is worth keeping an eye on and, thus, constitutes the focal interest of this investigation.

\section{Introduction}

Foreign language education in Japan has long been a critical issue for the country before the Meiji Restoration (1868-1945). Many series of reforms and policies have been generated to serve the need for the development of the country altered from westernization to globalization. With an attempt to understand $\mathrm{J}$ apanese e ducational reforms and policies from an outsider perspective in the $21^{\text {st }}$ century, it is noted that the background of the country and its population be sufficiently investigated.

Japan, one of the most influential leading countries in the world's economy and politics, is perceived as being wellequipped with technological advancement and an industrious, highly literate and energetic population. It is evident from the recent researches of historians into the state of education that one of the most characteristic features of Japanese people is their eagerness for knowledge. Japan has never been a society in which knowledge is a monopolized by a small part of the population, while leaving the masses uneducated and illiterate. Japan's literacy rate at the time of the collapse of the Tokugawa shogun ate in 1868 is estimated at 40 percent, a level that compares favorably with many advanced Western nations at the time. The generally 
high level of literacy already present in the country at that time became its advantage for its series of reforms, including when the swift introduction of foreign language and culture is needed.

From the time of the Meiji Restoration, studying foreign languages, to the Japanese, was a tool to facilitate the westernization (synonymous with 'modernization') of the country. Also, it was a key factor in Japan's recovery and rapid economic growth in the decades following the end of World War II (1945-1952). 'One of the original reasons that the Japanese had for studying foreign languages-and one that has continued to be important--is learning from the outside world' (Kitao, Kitao, Nozawa and Yamamoto,1994: http:// www. ling.lancs.ac.uk/staff/visitors/kenji/kitao/te $\mathrm{jk} \cdot \mathrm{htm})$.

After the postwar period (1960s'- present), however, the Japanese have also felt the necessity to express themselves as well as to communicate with the outside world. Foreign languages, previously seen as a tool to adopt western civilization, became the tool for two-way communication where ideas are shared and exchanged. This is due to the fact that with the arrival of the $21^{\text {st }}$ century, Japanese society is facing many more challenges as a result of changing cultural norms, advances in science and technology, and most importantly economic globalization.

While all these challenges require of the Japanese an ability to communicate in foreign languages, Japanese is the only language spoken by some $120,000,000$ people throughout the country with no bilingual district found (Hoshiyama, 1998). Accordingly, Japanese, the mother tongue, is used as the medium of instruction from the elementary school level up to the university level. Interestingly, although little exposure may have hindered the Japanese from acquiring target languages needed for different purposes across time, a wide range of efforts have continuously been made to remove constraints and enable its people to meet the needs of the country.

\section{The changing needs of the country: from westernization to globalization}

The reason why I view the needs of the country as an important factor in the Japanese acquiring a target language is that throughout the literature on the history of education in Japan, a continuously strong emphasis has been put on the development of the nation as an independent variable, while foreign language learning is one of the dependent variables. It means the policy regarding foreign language education has varied according to the changing situations of the nation.

\section{Chinese as the first foreign language in Japan}

In early times, Chinese was the most influential foreign language in Japan. The Japanese writing system is based on Kanji derived from Chinese ideographs and a great variety of expressions make use of them. Though Japanized in many ways, the Kanji characters form an essential part of the Japanese language (NIER, 2002).

\section{The era of westernization}

\section{The arrival of the Europeans in the early period}

The Japanese first came into contact with a European language, Portuguese, during the 
$16^{\text {th }} \mathrm{c}$ entury, and later in the $17^{\text {th }} \mathrm{c}$ entury with Dutch. English was first taught in Japan following the brief stop at Nagasaki of a British ship in 1808. Since the Japanese found that they could not communicate at all with the sailors from that ship, the Tokugawa government ordered the interpreters to add the study of English to their study of Dutch, French, and Russian (Omura, 1978). Their study of English, however, resulted in two books: Angeria Kokugowage (English Lessons for Beginners) and Angeria Gorintaisei (English Vocabulary, containing about 6,000 words).

\section{The force to open the country}

In 1853, Japan was forced to open the country up by the Americans, and the study of English began in earnest. Two major methods emerged early in the history of English teaching in Japan. One emphasized correct pronunciation as well as meaning (Seisoku), and the other emphasized meaning without regard to the correct pronunciation of the words, and without paying much attention to the rules of syntax (Hensoku) (Koike, 1978). It was observed that students who learned by the second method seemed to have better comprehension, while students who learned by the first method were compared to "reading machines" with correct pronunciation but with little understanding of what they were reading (Omura, 1978).

\section{The Meiji Restoration}

National attitudes leading to the Meiji Restoration (1867) and the formation of the Ministry of Education, Science and Culture (MEXT) show the growing awareness by the Japanese people of the importance of the English language. Public education, in general, was regarded as the means of national development and, at the time of Meiji, of westernization (or modernization). In this light, English became a tool used in the process of modernization. American and British instructors were welcomed to teach English, and courses in technology and philosophy were introduced via English.

According to Kitao, Kitao, Nozawa and Yamamoto (1994), in the 1890 's, a system of language teaching was established. English was compulsory in the middle and secondary schools. It was the main foreign language, while French and German were offered in schools as a second foreign language. Language study was closely associated with westernization. English was mostly taught by native English speakers, including many Christian missionaries. English medium classes were held at institutions of higher learning, and most textbooks came from the US. Many students developed a good command of English during this time. However, in the early 1900 's, foreign texts and teachers were gradually replaced by Japanese textbooks and teachers. Japanese scholars who had studied abroad became influential in the field of English language education. Some of their ideas seem amazingly contemporary. For example, Kanda Naibu advocated the use of the target language as much as possible in the classroom, exclusion or reduction of translation, extensive teaching of the target culture, and inductive learning of grammar. English became primarily a subject of study, mainly learned for the purpose of reading written texts, instead of a means of communication. In 1921, Harold E. Palmer, an English linguist and specialist in language teaching, was invited to Japan and became an advisor to the Ministry of Education. He advocated the Oral and Direct Methods. His methods were used in various parts of Japan and obtained good 
results. Unfortunately, they required a command of English far beyond that of most Japanese teachers of English and so the two methods never came into general use.

From the time of the Meiji Restoration (1868-1945), foreign language education was required in enabling the country to meet the challenges presented by the need to quickly acquire Western ideas, science, and technology. The foremost aim of the study of foreign languages has been the rapid acquisition and appropriation of the cultures and techniques of Western civilization (Morita, 1976). In other words, foreign languages, to the Japanese, was a tool to facilitate the westernization (synonymous with 'modernization') of the country. This supports the statement by Morita that 'the learning of foreign languages was then seen as a kind of service to the state' (Morita, 1976: 48).

\section{World War II}

Shortly before and during World War II, the study of English was discouraged, because it was the "enemy language". More and more emphasis was placed upon scientific and technological subjects which had a direct application to the war itself, and foreign language education tended to be neglected. Thus it came about that there was for a time a kind of intellectual and cultural 'closed-door policy' (Morita, 1976; p. 47), and its discontinuation at the end of the war an acute shortage of specialist teachers of English in intermediate education was felt. The aftermath of the shortage remained for twenty years or so which caused a gap in proficiency between the upper and lower age-groups of specialist teachers of English in the institutes of higher education.
However, this policy was reversed after the war. The American occupation brought a structural change to the school system: six years of primary school, three each of junior and senior high school (which were generally forced to become coeducational), and four years to receive the basic university degree. In 1947, the Fundamental Law of Education and the School Education Law were enacted and the 6-3-3-4 system of school education was established aiming at realizing the principle of equal opportunity for education. Education is compulsory through the third year of junior high school, but $94 \%$ of all Japanese junior high school graduates go on to high school (Nihon Kyoiku Nenkan Kanko linkai, 1985). Foreign languages are offered as electives in the reorganized junior high and high schools, and the most common foreign language is English.

The gradual recovery of the national economy, and in particular the period of high economic development in the latter half of the 1950's, linked with the unchanging enthusiasm for learning which the populace showed even during the years of the war, succeeded in making the new system effective, and since the 1960's the number of entrants to high schools and universities has increased phenomenally. The teaching foreign languages was in no way separated from the general trends. Since then, within the new system, English instruction became mandatory beginning in the first year of junior high school. This means learning of foreign languages became part of the syllabus at the level of compulsory education. The fact that the proportion of junior high school leavers entering high school was then more than $90 \%$ means that from then on nine out of every ten Japanese study English for six years. 
It is interesting to note that 'at no time since the war has the study of foreign languages been compulsory, nor has there been any restriction to English only as a subject of study but for various reasons English has been taught almost without exception' (Morita, 1976; p. 47). A wide range of efforts were put on learning English as the foreign language: (1) teacher training mainly in the universities, (2) approximately 16 kinds of lower secondary school English textbooks and 51 kinds of upper secondary school English textbooks published, (3) an attempt to adopt 'An Introduction to Transformational Grammars' introduced by Chomsky to English teaching, and (4) a rapid progress in the field of mechanical aids for language learning (including audio-visual aids in schools, and radio and television).

English education is very important in Japan. Almost all secondary students take English courses. English is offered in more than $99 \%$ of all junior highs and high schools (Hoshiyama, 1978), and almost all students take it, even though it is an elective (Kumabe, 1978). A foreign language is required for many university degrees, and most students take English. In addition, many people of all ages take English courses at English conversation schools, at the companies where they work, or through television or radio programs. Both radio and television offer English courses for different levels of ability, and hundreds of thousands of Japanese people study English this way. The main reason why the Japanese choose English as the foreign language of choice is the perception of English as the international language. According to Kitao, Kitao, Nozawa and Yamamoto (1994), for Japanese people, English is also a way to learn about other cultures. Since Japan is a homogeneous country, it is especially important for the Japanese to learn about various cultures, and the ways of living and ways of thinking of other peoples. Studying English is a way for them to do this.

During this period, speaking and aural comprehension of a language was recognized as the effective ways of teaching that language. However, in recent reports on the teaching of English in high schools, stress is laid on reading and grammar. This is due to the tendency to focus on reading and writing in school entrance examinations.

\section{The era of globalization}

Since the postwar period (1960's- present), foreign languages, to the Japanese, is not only a tool to facilitate the westernization of the country. In this era of globalization, the Japanese have also felt the necessity to express themselves to the outside world, to explain Japanese culture, ways of thinking, and positions on various issues to non-Japanese people (Hisano, 1976). As mentioned above, there is a paradigm shift from the emphasis on one-way communication towards a more dynamic two-way communication. An increasing number of Japanese people going abroad and foreigners visiting the country require the Japanese to have the ability to communicate as well as express themselves in English to non-Japanese people. Furthermore, at the arrival of the $21^{\text {st }}$ century, Japanese society is facing many more challenges as a result of changing cultural norms, advances in science and technology, and economic globalization. Nurturing young people who can meet these $\mathrm{c}$ hallenges is still a critical task for Japanese education. A wide range of reforms are already underway throughout the education system, from the elementary school level to university. National policy 
on education has been continuously updated. International exchange and cooperation has been made. Japanese people always seek opportunities to improve their English ability. A number of researches have been conducted aiming to improve the quality of foreign language teaching and learning in Japan.

\section{National policy on foreign language education}

In 2002, the Japanese Ministry of Education, Culture, Sports, Science and Technology (MEXT) launched a policy for the improvement of communication skills in English. MEXT views that with the progress of globalization in the economy and in society, it is essential that Japanese children acquire communication skills in English, which has become a common international language, in order to function in the $21 \mathrm{st}$ century. Globalization has provided each individual increasing opportunities to come in contact with the global market and services, and participate in international activities. It has become possible for anyone to become active on a world level. Furthermore, due to progress in the information technology revolution, a wide range of activities, from daily life to economic activities, are being influenced by the movement toward a knowledge-based society driven by the forces of knowledge and information. Thus, there is a strong demand for the abilities to obtain and understand knowledge and information as well as the abilities to transmit information and to engage in communication. MEXT (2003) viewed that in such a situation, English has played a central role as the common international language in linking people who have different mother tongues. MEXT believe that English abilities are important in terms of linking Japan with the rest of the world, obtaining the world's understanding and trust, enhancing Japan's international presence and further developing the nation.

This has become an extremely important issue both in terms of the future of Japanese children and the further development of Japan as a nation. MEXT argued that at present, the Englishspeaking ability of a large percentage of the population is inadequate, and this imposes restrictions on exchanges with foreigners and limits occasions when the ideas and opinions of Japanese people are not appropriately evaluated. Accordingly, the ministry has formulated a strategy to cultivate "Japanese with English abilities" in a concrete action plan with the aim of drastically improving the English education of Japanese people. (see http ://www. mext. go.jp/english/news/2002/07/020901.htm for further details on the strategic plan)

\section{Reformation in the education system}

\section{Elementary school level}

There are three types of elementary schools in Japan--public elementary schools, elementary schools attached to national universities, and private elementary schools. More than $99 \%$ of the elementary schools in Japan are of the first type. They are controlled by the Ministry of Education, and their curricula do not include foreign languages. Some of the private and university-associated elementary schools provide English courses. So less than $1 \%$ of the elementary schools in Japan offer English (Nogami, 1978). Some of them offer English as part of the regular curriculum; others only offer it occasionally as an extra-curricular activity. English classes at the elementary level tend to emphasize oral/aural English rather 
than reading, and a few of them even have language laboratories.

Since 2002, activities in foreign languages (conversations in English, etc.) have been taught in public elementary schools in "Period of Integrated S tudies" as p art of "International Understanding Studies." Among foreign languages (French, German, Chinese, Korean, Russian, etc.), English is most popular. According to a research conducted by MEXT in 2002, "English activities" (more precisely, communication activities in English) have already been introduced into about a half of public elementary schools all over the country. Since the activities are not yet prescribed, there is a variety in terms of the content and frequency offered. For example, some schools have only three periods (1 period $=40$ minutes) of English activities a year, while some schools have 2 periods a week, i.e., 70 periods a year. Some schools have English activities with young native English speakers invited by the Japan Exchange and Teaching (JET) Program. A school in Tokyo has a plan to make some special classes where students study all the subjects in English. Schools in Yokohama city, a famous international harbor city in Kanagawa prefecture, provide communication activities in as many as 16 foreign languages. In the future, English will be officially introduced in the regular curriculum of elementary schools, but at present, it is under consideration by MEXT as to how it should be implemented.

\section{Lower secondary school level (junior high schools)}

In the New Courses of Study for Lower and Upper Secondary Schools (2003), foreign languages have become compulsory subjects, and greater emphasis is placed on the cultivation of fundamental and practical communication abilities. Since then, all Japanese students start studying English when they enter the first year of junior high school at age twelve. Previously, although English was not a required subject in lower secondary schools, due to the fact that English is an important factor - often a decisive oneon high school and university entrance examinations, almost all lower secondary school students took English (Kumabe, 1978).

The content of the English courses offered in public lower secondary schools is dictated by the Ministry of Education's Course of Study. According to the Course of Study (2003), the purpose of English education is to develop students' basic practical communication abilities such as listening and speaking, as well as understanding of language and culture, and fostering a positive attitude toward communication through foreign languages. The content through 3 -year periods is divided into 3 levels namely Language activities in Grade 1, 2 and 3. Since Language activities in Grade 1 is the start of English learning, emphasis is given to raising in students a positive attitude toward communication. Language activities involving familiar language-use situations and functions of language are carried out. At this stage of learning, topics are drawn on simple communicative expressions related to students' feelings and familiar happenings. Language activities in Grade 2 include a further widening of the language-use situations and functions of language. At this stage of learning, the conveying of factual information and judgments are taken up, in addition to topics aiming for communication in Grade 1. Language activities in Grade 3 include an even further widening of the languageuse situations and functions of language 
should be carried out on the basis of what was learned in Grade 2. The expressions of various thoughts and opinions are taken up in addition to topics in Grade 2.

English taught in junior high school is particularly important. For most students, this is their first formal education in English, and it is important that they make a good beginning. However, according to Kitao, Kitao, Nozawa and Yamamoto (1994), classes are relatively large--about forty students in each class. Many students start studying English in junior high school with eager anticipation. Unfortunately, due to the emphasis on memorization and learning about English, rather than u sing English for the purpose of communication, many lose interest, and it gradually becomes their least favorite subject.

\section{Upper secondary school level (high schools)}

In upper secondary education, which is non-compulsory, the aim of English teaching is practically the same as in lower secondary schools. High school English classes are also controlled by the guidelines in the Ministry of Education's Course of Study (2003). The goals of English classes listed in the Course of Study for Upper Secondary Schools 2003 is to develop students' practical communication abilities such as understanding information and the speaker's or writer's intentions, and expressing their own ideas, deepening the understanding of language and culture, and fostering a positive attitude toward communication through foreign languages.

Six courses provided for upper secondary school students are English I and II, Aural/Oral Communication I and II, reading and writing. English I and II aim to develop students' basic abilities to understand what they listen to or read and to convey information, ideas, etc. by speaking or writing in English, and to foster a positive attitude toward communication through dealing with everyday topics. In Aural/ Oral Communication I, the students are required to be able to understand and convey information, ideas, etc. by listening to or speaking English, and to have a positive attitude toward communication through dealing with everyday topics. Additionally in Aural/ Oral Communication II, the students will have a chance to organize, present and discuss information, ideas, etc. in English. Reading and writing courses provide a wide range of communicative activities to develop the students' ability in particular skills. Reading course requires the students to (1) obtain necessary information, to make an outline, and to summarize the main points by reading texts, (2) understand the writer's intentions etc. and to organize and transmit one's own ideas e tc. a bout them by r eading texts (3) read stories etc. and talk or write about one's own impressions, and (4) read passages aloud so that the content and one's interpretation can be transmitted to the listener. In writing course the students participate in such activities as (1) writing down the outline and the main points of what has been listened to or read in accordance with the situation and the purpose, (2) organizing and writing down their own ideas etc. of what has been listened to or read, and (3) organizing and writing down their intended messages in accordance with the situation and the purpose so that they can be understood by the reader.

Since the policy has just been issued in 2003, there is still no investigation of the application available. To get an insight into the practice 
of English teaching in upper secondary level, I refer to the article by Kitao, Kitao, Nozawa and Yamamoto (1994) arguing that the content of high school English courses is heavily influenced by the content of university entrance examinations. Also, there is a large gap between the level of English in the third year of junior high school and the first year of high school. The typical high school English class is based on a reader and grammar book. Like junior high textbooks, they must be approved by the Ministry of Education. In the case of high school textbooks, the texts are chosen by the school. Still, the individual teacher has little control over the textbooks. Students prepare for a class in advance by writing Japanese equivalents next to English words and phrases. In class, a student reads the resulting translation. The teacher reads a model or correct translation and comments on difficult grammatical points. The teacher also models reading aloud the English version of the lesson, and students repeat after the teacher (Hisano, 1976). For grammar classes, the text is divided into grammatical categories. Each category is accompanied by examples, explanations, and exercises. Composition classes consist of translation of Japanese into English, not free writing.

Private schools often have more hours of English per week than do public schools. They typically offer five to six hours of reading and one to two hours of conversation. At the upper secondary school level, even now the subject of English is not required, but elective. Other foreign languages (e.g., German, French, etc.) can be taught as an elective subject as well. Nevertheless, most schools do not teach foreign languages other than English. However, recently it is becoming more and more popular to teach languages of neighboring countries, such as Chinese and Korean, at upper secondary schools.

In sum, teaching English in practice according to Kitao, Kitao, Nozawa and Yamamoto (1994) still seems to be far from the objectives in Course of Study issued by the ministry in 2003. I believe that follow up studies will soon be conducted by the ministry after the policy has been further implemented.

\section{University/college level}

Most four-year universities require all students to take two foreign languages. NonEnglish majors take a minimum of eight to twelve credits in the first foreign language --usually English--and four credits in the second--usually French or German. In some universities Russian, Spanish or Chinese is offered. All these modern languages are taught as a preparatory or auxiliary subject for specialized studies, in the first two years. In junior colleges (two-year course), non-English majors take two to four credits of English or French while more than 46 credits in the course of the English Language and Literature (English majors).

National and private universities/colleges provide classes of various foreign languages. According to an official document on the educational policy of MEXT issued in 1989, more than 50 foreign languages in total were taught in universities/colleges in Japan. English and German are taught in more than $90 \%$ of the universities/ colleges, and French is taught at more than $70 \%$ of them. Osaka University of Foreign Studies (OUFS) also conducted research on foreign languages education at the university/college level. The result reveals that in 1990 the following languages were popular as a major subject or a subject specialized for a particular department in 
70 universities/colleges (those who replied to the questionnaire): (1) English is taught at $98 \%$, (2) German, 95\%, (3) French, $88 \%$, (4) Chinese, $58 \%$, (5) Russian, $35 \%$, (6) Spanish, 26\%, (7) Korean, 9\%, (8) Latin, 7\%, (9) Italian, 4\%, (10) Greek, $1 \%$, (11) Portuguese, $1 \%$, (12) Indonesia, $1 \%$, and so on. Apart from these languages, Hebrew, Sanskrit, Arabic and Thai are also widely taught at particular faculties. A figure of the official statistics released by MEXT in 2002, on the other hand, shows that the following languages are popular: (1) English which is taught at 677 universities/colleges, (2) German, 577, (3) French, 543, (4) Chinese, 568, (5) Korean, 322, (6) Spanish, 240, (7) Russian, 189, (8) Latin, 103 (9) Italian, 99, and (10) Arabic, 44. From the s tatistics a bove, we can see that in recent years Korean is becoming more popular whereas Russian is becoming less popular.

The result of the research by OUFS in 1990 also shows that the number of available foreign languages as a subject specialized for a particular department differs among faculties, as follows:

22 foreign languages are taught at the Faculty of Liberal Arts

21 at the Faculty of Arts

17 at the Faculty of Foreign Languages

9 at the Faculty of International Affairs and Faculty of Economics

8 at the Faculty of Law

7 at the Faculty of Arts and Sciences, Faculty of International Studies, and Faculty of Social Studies

6 at the Faculty of International Cultures, Faculty of Humanities

5 at the Faculty of Education, Faculty of Administration and Social Studies, Faculty of Commercial Science, Faculty of Fine Arts, and Faculty of Music
4 at the Faculty of Engineering, and Faculty of Integrated Science

3 at the Faculty of Buddhism, Faculty of Law and Arts, Faculty of Social Science and Economics, and Faculty of Pharmaceutics 2 at the Faculty of Theology, Faculty of Science and Engineering, and Faculty of Agriculture

1 at the Faculty of Business Administration, Faculty of Business Administration and Information Science, Faculty of Physical Science, and Faculty of Dentistry

At the university level, most English classes are reading classes. Professors generally ask students in the reading class to translate sentences into Japanese, covering from five to ten pages of the textbook in the ninety-minute class period (Koike, 1982). Most textbooks contain essays or prose, so students do not have opportunities to develop strategies for dealing with other literary forms, such as dialogues, newspaper articles, advertisements, brochures, etc. (Kitao and Kitao, 1982). Studies of students' reading ability show that they have particular difficulties in dealing with these types of literary forms (Kitao and Miyamoto, 1982).

In addition, what most Japanese students consider reading is finding a Japanese equivalent for each English word. They know the meaning of each word in Japanese and of the individual Japanese sentences that they have formed, but they do not understand how the individual sentences fit together or what the meaning of the passage as a whole is (Kitao, 1983). This causes them to read slowly, usually only 50-100 words per minute. Their reading speed also cause the students difficulty in reading for comprehending the overall content and understanding the main idea of a certain passage (Kitao and Miyamoto, 1983). 
Finally, the common problem that students have with English is that they do not know much about English-speaking cultures. Since language and culture are closely linked, knowledge of the target culture is necessary for successful communication, but culture is taught neither extensively nor well in English classes in Japan (Kitao, 1978). According to Kitao, many Japanese say that they can read English, but they cannot speak it. I also conducted a survey with a group of Japanese students in Thailand on 'English study in Japan.' All informants said that they can read English, but they cannot speak the language. This issue seems to be the most mentioned when talking about English language education in Japan.

\section{University Entrance Examinations}

University entrance examinations usually include sections on translation from English into Japanese, reading passages with questions on the content, and items where students must choose the correct word to fill in the blank, to test knowledge of grammar, as well as questions on points of prescriptive grammar, often hair-splitting points. Some questions are so difficult and tricky that even native English speakers have difficulty answering them (Ogasawara, 1983). The entrance examinations do not emphasize English as it is actually used but rather "grammar book English". Most examinations do not require performance in English. Even translation items put more emphasis on understanding the nuances of grammar, rather than on the ability to express oneself in English (Kumabe, 1978). Only a very few entrance examinations include sections that test students' ability in aural English. Entrance examinations require considerable knowledge about English, but offer little or no opportunity to demonstrate ability to perform in English. The entrance examination has been the most criticized issue that is calling for a prompt reformation.

\section{International Exchange and Cooperation: JET program}

The Japan Exchange and T eaching (JET) Program was established in 1987. It invites young college and university graduates from o verseas to $\mathrm{p}$ articipate in international exchange and foreign language education throughout Japan. The program has earned a high reputation, both in Japan and overseas, for its efforts in human and cultural exchanges, and has become one of the largest cultural exchange programs in the world.

Aiming to promote foreign language education, MEXT invited 5,676 young people from overseas through the JET Program to serve foreign language education at schools as Assistant Language Teachers (ALTs) in the fiscal year 2002. MEXT also continues to promote domestic training and overseas dispatch programs for lower and upper secondary school English teachers. In addition, MEXT has prepared a teacher manual and is committed to implementing teacher training to support English conversation study at elementary schools.

From FY2002, MEXT has designated designate "Super English Language High Schools" to pursue practical research and development that will contribute to future improvements in English language education, and "Foreign Language Education Diversification Community Projects" have been implemented to promote the diversification of foreign language education. In addition, elementary school ALTs have been newly assigned within the JET Program. 


\section{Opportunities sought to improve English abilities}

\section{Studying abroad}

The total number of Japanese students studying abroad in 2000 was 76,464 . They went to the following countries mainly: USA, 46,497; China, 13,806; UK, 6,163; Australia, 2,200; Germany, 2,040; France, 1,446; Canada, 1,478; New Zealand, 680; The Republic of Korea, 613; and Austria, 302. According to the Institute of International Education (IIE), among Japanese students studying in USA in 2001-2002, $67.5 \%$ were students at the undergraduate level, $20.7 \%$ were students at the graduate level, and $11.8 \%$ were others (e.g. students in a short program). In addition, $44.5 \%$ were male students and $55.5 \%$ were female students.

\section{English in Private Language Schools}

An interesting component of Japanese education is the thriving industry of "juku" and "yobiko", after school "cram schools," where a pproximately $60 \%$ of J apanese high school students go for supplementary lessons. Juku may offer lessons in non-academic subjects such as art, swimming, abacus, and calligraphy, especially for elementary school students, as well as the academic subjects that are important to preparation for entrance examinations at all levels. Juku for high school students must compete for enrollment with yobiko, which exist solely to prepare students for university entrance examinations. Juku and yobiko are primarily private profit $s$ chools that attract students from a wide geographical area. They often are located near train stations, enabling students to transport themselves easily to them directly from school.
Some elementary-level students study English at juku that offers private tutoring in various subjects. In Tokyo area, thirty percent of the elementary school students (Nihon Kodomo o Mamoru Kai, 1984) and seventy-five percent of the lower secondary school students attend juku (Kitao, Kitao, Nozawa and Yamamoto, 1994). Private language schools are even more popular among high school and college students because in high schools and colleges classes are large. Most of the classes depend heavily on translation, do not offer much opportunity to build skills in aural/oral English, include students of widely varying proficiency, and have relatively few native English speakers as teachers (Oura and Tada, 1978). On the contrary, the aims of English classes in private schools are usually practical. Classes are usually small, compared to those in high schools and colleges. Students are, in theory, placed according to their level of ability in English rather than their age or grade level. However, in practice, classes may be combined so that students of different levels are in the same class. Students attend language schools for a variety of reasons. Some feel that it will be useful on the job; others plan to use it while traveling abroad or receiving foreign guests. For some students, studying English is mainly a hobby. Others see it as proof of intellectual attainment (since people who can understand English are considered well educated) or a way to learn more about other cultures, since language schools put more emphasis on studying the cultures of Englishspeaking countries than do high schools or colleges (Oura and Tada, 1978). They stress improving students' English proficiency and communication skills, especially in interpersonal communication. They also emphasize increasing students' knowledge 
of English-speaking cultures and making them "international persons" (Itabashi, 1978).

The format of classes in language schools varies widely. Some emphasize mainly oral/aural skills. Others offer classes in the four skills, either together or in different classes. Oral/aural classes are skill-based and communication-oriented. Reading classes in a language school would be likely to concentrate on extensive reading, in contrast to the intensive reading and translation generally found in high school or college reading classes. Writing classes focus on development of structural patterns and idiomatic expressions in free writing rather than translation (Nozawa, 1984).

Teachers in language schools tend to prefer textbooks to be current English textbooks or culture-oriented texts. They usually avoid the works of literature favored by college professors, preferring to give their students a more up-to-date exposure to English.

Language schools often have some sort of objective criteria for judging the progress that their students make. For example, criteria for listening skills might be $60 \%$ comprehension of the $n$ ews or more than fifty points on the listening section of the TOEFL.

Because language schools emphasize the practical aspects of oral English and teaching a bout English s peaking c ultures, many of them have a variety of teaching media available for teachers, including tape recorders, language laboratories, films, video tapes, and slides. Teachers use tape recorders most frequently. Language laboratories seem to be underused in many language schools, since some teachers feel that it is too complicated and difficult to use or there is not enough good software available for language teaching. Recently, some schools have obtained computers, but they, too, tend to be underused due to a lack of good software (Nozawa, 1984).

Many native English speakers are hired as teachers in language schools, either part time or full time. Most of them teach aural/oral English classes. Some teach composition (Nozawa, 1984).

\section{Company English Programs}

In Japan, many companies provide their employees language classes. Since Japanese employees usually stay with the same company for their entire working life, Japanese companies spend a relatively large amount of money on training for their employees. When the need arises for employees to attain a certain skill, Japanese companies train existing employees rather than hiring new employees with that skill (Takubo, 1978). Many of these companies need employees with a higher proficiency in foreign languages, mainly English, and skill in communicating with non-Japanese people in order to carry on business activities effectively. Some offer English classes solely for the purpose of self-development.

The companies most likely to offer language programs to their employees are manufacturing companies (Kitao, 1984). This is due to the fact that Japanese manufacturing companies have been rapidly expanding their international activities, and because their employees do not generally have much background in foreign languages. Company classes usually emphasize speaking English and comprehending spoken English. Companies who offer English classes seem to feel that oral/aural skills are the most important for their employees. 
Company programs fall into three major categories: in-company programs, out-ofcompany programs, and study abroad. (Hashimoto and Lau, 1983). The most common company programs are incompany programs. Most companies who offer in-company English classes contract to offer them through private language schools. These language schools handle the administrative and technical aspects of the program, including hiring teachers, choosing or developing texts and materials, and deciding on methods to be used. However, the person within the company who is responsible for the language program is not usually a professional in the language education field.

Since in-company programs emphasize oral/aural skills, most of the teachers hired to teach in them are native English speakers. Some of these companies hold classes during working hours, and others, after working hours. A few companies offer classes before working hours. Some of the companies that offer English classes include proficiency testing for those about to study abroad or for the purpose of motivating employees. A few of these companies use their own testing system, but most rely on such standard tests as STEP, TOEFL, TOEIC and the Michigan Test. Some companies send employees to outside language institutes for language learning. Companies that do this pay either all or part of the fees for the language classes. In some cases, the amount of aid depends on the employee's success in the course. Employees go to these classes during or after working hours. Some companies send employees abroad specifically to improve their language proficiency. These employees either train in universities or in related companies. Some of the companies that send employees overseas for language training require their employees to stay with the company for a specified period of t ime a fter their return to Japan. Employees are sometimes rewarded for successful completion of the study-abroad program by being made candidates for further training for the company's international activities or are immediately transferred to a p osition that allows him/her to use the language abilities developed abroad.

Company employees need more than linguistic competence. Some Japanese companies have begun to include an intercultural component to help their employees learn to communicate with native English speakers on business and social levels. The intercultural component develops intercultural communication skills and gives students a greater appreciation of their own as well as others' cultures (Takubo, 1978).

\section{Researches related to foreign language education in Japan in the $21^{\text {st }}$ century}

I conducted a review of research articles related to foreign language education in Japan during 2000-2004 in 9 refereed journals: Language Learning, Modern Language Journal, SYSTEM, Language Learning \& Technology, Computer-Assisted Language Learning, JALT, JALT-CALL, the Language Teacher, and CALL-EJ. The last four journals are Japan-based ones. The results revealed that the body of research contains a wide range of research areas relevant to many different dimensions of foreign language teaching and learning in Japan. The most interesting research theme that I will discuss in this paper is the uses of technology for language learning due to the fact that Japan is one of the leading countries in terms of technological advancement, and the extent to which technology has been used in 
foreign language education after the turn of the $21^{\text {st }}$ century.

The findings show that computer and network technology have widely been integrated in schools and universities. More interestingly, some educators started to consider using wireless network technology like mobile phones in language teaching and learning.

\section{Uses of computers and network technology for teachers and students.}

The "One Hundred Schools Project," which started in 1995, provided computer software and Internet connections for more than one hundred primary and secondary schools. The schools chosen for this project are ones that are located in central areas in their prefectures or in their urban areas. While this project is not specifically intended for English language teaching, it has made the Internet available to English teachers and students in junior highs and high schools. Most universities have computers with Internet access, though universities vary in the degree to which computers are available to students and also in how much they are used in the classroom. However, there s eems to be a growing interest in how to teach English with computers, especially among younger teachers.

Computers are used in various ways in English education. The traditional ways to use computers in English courses is to present exercises. For example, students are presented with a reading passage followed by comprehension questions or a grammar or vocabulary question. Students answer a question, and the computer compares the answer that the student has provided with the specified correct answer, and gives the student feedback whether the answer is right or wrong. Computers have the potential to give immediate feedback on the answers to individual questions and also on the students' overall score and time. More sophisticated programs make use of pictures and sound and allow students to branch, depending on their level of proficiency. B ranching a llows s tudents to work on questions that suit their particular strengths and weaknesses.

With the spread of access to the Internet, the possibilities for using computers in language classes have greatly expanded. Some of the traditional types of language teaching exercises are available on the Web, and these can be very useful for students. However, a number of other activities allow students and teachers to make use of some of the unique characteristics of the Internet. For classroom teachers, there are a great many resources available on the Internet. $D$ iscussion lists allow teachers in Japan to discuss issues with teachers from all over the world. There are also lesson plans and other materials posted on Web pages.

One type of resource for students on the Internet is student lists, which are discussion lists especially for students of English as a second or foreign language. These allow students to use e-mail to discuss topics of mutual interest with other students. There are several Web pages through which either teachers can make contact with other teachers so that their classes can do key pal projects or individual students can contact other individual students. In the case of classes doing key pal projects, students can often be given a specific topic about which they can exchange information, such as an aspect of their culture. 
Another way that language teachers can use the Internet is to have students write about a particular topic and post their writing on the Internet. For example, one teacher has had students write about famous Japanese people. People who read the passages on the Internet can send a message commenting on the writing. In addition to doing individual or class projects to be posted on the Web, students can do projects arranged by their teachers in c ooperation with other classes, e ven if the students in other classes are in a different country. Electronic bulletin board, Electronic chat, and E-mail have made it simple for students who are widely separated distance to communicate and collaborate. Several of the schools involved in the Ministry of Education's 100 Schools project have done Web page projects with sister schools in other countries. Projects posted on the Web give students a chance to write something that readers may be interested in and get responses to what they have written. This provides a more realistic--and more interactive--situation for writing than EFL students normally get.

A third major way that students can use the Internet is as a source of information. For almost any subject that students would want to research, there is information on the World Wide Web. While the use of the Web cannot replace library research, the Web is a great treasure house of information.

\section{Uses of mobile phone}

Dias (2002) reported in the newsletter of the JALT-CALL Special Interest Group on the embodiment of mobile communications and networking: cell phones and their possible application to language teaching. He first conducted a survey on cell phone usage habits among Japanese university freshmen: how the students were using their cell phones--what proportion used them and, of those, how many had handsets that were email/Web capable and what exactly were their usage patterns. Did they use them more for texting, speaking, or as calculators and alarm clocks? The results showed that the majority of both male (53.7) and female (71.3) students said they could not live without a cell phone. It was also revealed that $73 \%$ of students had access to the Web on their cell phones and, for most of them this was their primary method for accessing it. Male and female students showed similar tastes in on-line content, with melody/ MP3 sites at the top of list, followed by weather/transport information, and navigation. News was considerably more popular with male students. Female students were more than twice as likely to access fortune telling sites as their male counterparts.

Equipped with the information gleaned from these survey questions Dias decided to set up a Bulletin Board that was accessible from practically all the cell phone types used by the students, and create a site of cell phone-friendly links to language learning and English content sites.

\section{Conclusion}

Although English is considered a foreign language in a monolingual society like Japan, there is a huge movement to encourage people to gain their proficiency in English. The aim of expressing themselves to the world is as much of interest as the efforts the country put forth towards the development of English language abilities of its people. The growing potential of the application of technology to language 
education in Japan is what the world should keep an eye on.

\section{References}

Dias, Joseph. 2002. "Cell phone in the classroom: boon or bane?" CALLing Japan, 10 (2).

Hashimoto, S., \& Lau, L. 1983. “A survey of in-company English teaching programs". ELEC Bulletin, 55-56.

Hisano, K. 1976. A handbook for teaching English to Japanese. Unpublished master's thesis. Brattleburo, Vermont: School for International Training.

Hoshiyama, S. 1978. "History of English teaching in Japan". Postwar (after 1945): A general survey of TEFL in Postwar Japan. In The teaching of English in Japan, Ikuo Koike (Ed.), Tokyo: Eichosha.

Imura, M. 1978. "Junior high school: English teaching policies for lower secondary schools". In The Teaching of English in Japan, Ikuo Koike (Ed.). Tokyo: Eichosha.

Itabashi, N. 1978. "Adult education: English teaching at a language school". In The Teaching of English in Japan, Ikuo Koike (Ed.). Tokyo: Eichosha.

Kitao, K. 1978. "A survey of the teaching of American culture with K.U. Japanese students". Doshisha Studies in English, 19.

Kitao, K., \& Kitao, S. K. 1982. "College reading textbooks do not meet needs". The Daily Yomiuri.

Kitao, K., \& Miyamoto, H. 1982. "Japanese college students' English reading ability--A study based on testing". Doshisha Studies in English, 30.

Kitao, K., \& Miyamoto, H. 1983. "Japanese college students' problems in reading English--Tendencies and changes in errors". Doshisha Studies in English, 32.

Kitao, K. 1983. "Common misconceptions about "reading English."” The Daily Yomiuri.

Kitao, K. 1984. The Second In-Company Language Program Seminar. JALT Newsletter, 8(1).

Kitao, K., Kitao, S. K., Nozawa, K. and Yamamoto, M. 1994. "Teaching English in Japan". Retrieved September 11, 2004 fromhttp://www.ling.lancs.ac.uk/staff/ visitors/kenji/kitao/tejk.htm

Kitao, K., \& Kitao, S. K. 1995. English Teaching: Theory, Research, Practice. Tokyo: Eichosha.

Koike, I. 1982. "The teaching of English in Japan". The Proceedings of the College English Teachers Association for the Second International Conference, Supplement to English Teaching, 24.

Koike, Ikuo. 1978. "English Language Teaching Policies in Japan: Past, Present, and Future". In The Teaching of English in Japan, Ikuo Koike et al (eds). Tokyo: Eichosha.

Kumabe, N. 1978. "Senior high school: Some ways to improve it". In The Teaching of English in Japan, Ikuo Koike (Ed.). Tokyo: Eichosha.

Monbusho (The Ministry of Education). 1979. Koto gakko gakushu shido yoriyo kaisetsu gaikokugo eigohen (Explanation of the Course of Study for High School, Foreign Languages, English Edition). Tokyo: Hitotsubashi Shuppan.

Morita, Ichiro. 1976. Foreign-Language Education in Japan: Past, Present and Future. Kyoto: Kyoto University of Foreign Studies.

Nihon Kodomo o Mamoru Kai (Japan Association for the Protection of 
Children). 1984. White paper on

children. Tokyo: Sodo Bunka.

Nihon Kyoiku Nenkan Kanko linkai

(Japan Education Yearbook

Publication Committee). 1985. Nihon

Kyoiku Nenkan (Japan Education

Yearbook), 1985 Edition. Tokyo:

Gyosei.

Nogami, M. 1978. "Elementary school:

The importance of TEFL for children". In The Teaching of English in Japan, Ikuo Koike (Ed.). Tokyo:

Eichosha.

Nozawa, K. 1984. “A preliminary study of English language teaching at senmon gakko in Japan: Teachers' view". The Lark Hill--Bulletin of the School of Humanities and Social Engineering of Toyohashi University of Technology, 7.

National Institute for Educational Policy Research (NIER). 2002. Trends in Foreign/Second Language Education in Asia and the Pacific. Tokyo, Japan: NIER.

Ogasawara, L. 1983. "The educational system and English in Japan". ELEC Bulletin, 55-56.

Omura, Kiyoshi. 1978. "History of English Teaching in Japan: Prewar (before 1945): From the Phaeton Incident up to the Pacific War". In The Teaching of English in Japan, Ikuo Koike et al (eds). Tokyo: Eichosha Publishing.

Takubo, K. 1978. "EFL in Japanese industry: Activities, problems, and solutions". Cross Currents, 5.

Torii, T. 1983. The training of English teachers in Postwar Japan. ELEC Bulletin, 55-56.

The Institute of International Education (IIE). Retrieved July 28, 2004 from http://www.iie.org.

The Japanese Ministry of Education, Culture, Sports, Science and
Technology (MEXT). 1989. The educational policy. Retrieved July 28, 2004 from http://www.mext.go.jp/hakusyo/book/ hpad198901/hpad198901_2_204.html.

The Japanese Ministry of Education, Culture, Sports, Science and Technology (MEXT). 2002. The official statistics. Retrieved July 28 , 2004 from

http://www.mext.go.jp/b_menu/houdo u/16/03/04032301.htm

The Japanese Ministry of Education, Culture, Sports, Science and Technology (MEXT). 2002. Developing a strategic plan to cultivate "Japanese With English Abilities." Retrieved July 28, 2004 from http://www.mext.go.jp/english/news/2 002/07/020901.htm

The Japanese Ministry of Education, Culture, Sports, Science and Technology (MEXT). 2003. The policy for the improvement of communication skills in English. Retrieved July 28, 2004 from http://www.mext.go.jp/english/news/2 002/07/020901.htm

The Japanese Ministry of Education, Culture, Sports, Science and Technology (MEXT). 2003. The Course of Study for Foreign Languages. Retrieved July 28, 2004 from http://www.mext.go.jp/english/shotou/ 030301.htm

The Japanese Ministry of Education, Culture, Sports, Science and Technology (MEXT). 2003. Regarding the Establishment of an Action Plan to Cultivate "Japanese with English Abilities". Retrieved July 28, 2004 from http://www.mext.go.jp/english/shotou/ 030301.htm 
The Japan Exchange and Teaching (JET)

Program. Retrieved July 28, 2004

from

http://www.mofa.go.jp/j_info/visit/jet/ outline.html. 